\title{
Takifugu obscurus is a euryhaline fugu species very close to Takifugu rubripes and suitable for studying osmoregulation Akira Kato ${ }^{1}$, Hiroyuki Doi ${ }^{2}$, Tsutomu Nakada1, Harumi Sakai ${ }^{3}$ and Shigehisa Hirose ${ }^{* 1}$
}

\author{
Address: ${ }^{1}$ Department of Biological Sciences, Tokyo Institute of Technology, Yokohama, Japan, ${ }^{2}$ Shimonoseki Marine Science Museum \\ "Kaikyokan", Shimonoseki Academy of Marine Science, Shimonoseki, Japan and 3Department of Applied Aquabiology, National Fisheries \\ University, Shimonoseki, Japan \\ Email: Akira Kato - akirkato@bio.titech.ac.jp; Hiroyuki Doi - doi@kaikyokan.com; Tsutomu Nakada - tnakada@bio.titech.ac.jp; \\ Harumi Sakai - sakaih@fish-u.ac.jp; Shigehisa Hirose* - shirose@bio.titech.ac.jp \\ * Corresponding author
}

Published: 20 December 2005

BMC Physiology 2005, 5:18 doi:10.1 186/1472-6793-5-18
Received: 09 July 2005

Accepted: 20 December 2005

This article is available from: http://www.biomedcentral.com/1472-6793/5//8

(c) 2005 Kato et al; licensee BioMed Central Ltd.

This is an Open Access article distributed under the terms of the Creative Commons Attribution License (http://creativecommons.org/licenses/by/2.0), which permits unrestricted use, distribution, and reproduction in any medium, provided the original work is properly cited.

\begin{abstract}
Background: The genome sequence of the pufferfish Takifugu rubripes is an enormously useful tool in the molecular physiology of fish. Euryhaline fish that can survive both in freshwater (FW) and seawater (SW) are also very useful for studying fish physiology, especially osmoregulation. Recently we learned that there is a pufferfish, Takifugu obscurus, common name "mefugu" that migrates into FW to spawn. If $T$. obscurus is indeed a euryhaline fish and shares a high sequence homology with T. rubripes, it will become a superior animal model for studying the mechanism of osmoregulation. We have therefore determined its euryhalinity and phylogenetic relationship to the members of the Takifugu family.

Results: The following six Takifugu species were used for the analyses: T. obscurus, T. rubripes, $T$. niphobles, $T$. pardalis, $T$. poecilonotus, and $T$. porphyreus. When transferred to FW, only $T$. obscurus could survive while the others could not survive more than ten days in FW. During this course of FW adaptation, serum $\mathrm{Na}^{+}$concentration of $T$. obscurus decreased only slightly, but a rapid and large decrease occurred even in the case of $T$. niphobles, a peripheral fresh water species that is often seen in brackish river mouths. Phylogenetic analysis using nucleotide sequences of the mitochondrial $16 \mathrm{~S}$ ribosomal RNA gene of each species indicated that the six Takifugu species are very closely related with each other.

Conclusion: T. obscurus is capable of adapting to both FW and SW. Its genomic sequence shares a very high homology with those of the other Takifugu species such that the existing Takifugu genomic information resources can be utilized. These properties make "mefugu", which has drawn little attention from animal physiologists until this study, a useful model animal for studying the molecular mechanism of maintaining body fluid homeostasis.
\end{abstract}

\section{Background}

Maintenance of a stable internal environment is important for vertebrate animals to survive in a variety of habi- tats. Even small changes in ionic balance, osmolarity, and $\mathrm{pH}$ of body fluid seriously affect the survival of the animals. Strategies for maintaining body fluid homeostasis 


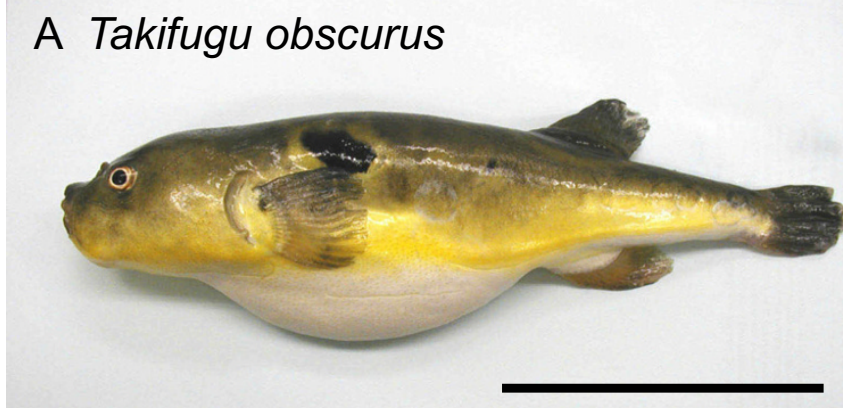

C Takifugu niphobles

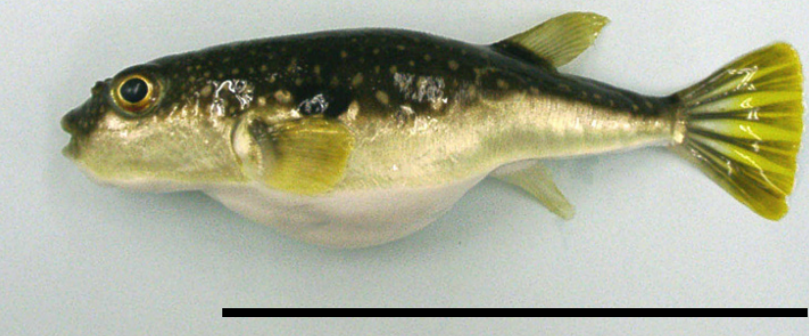

E Takifugu poecilonotus

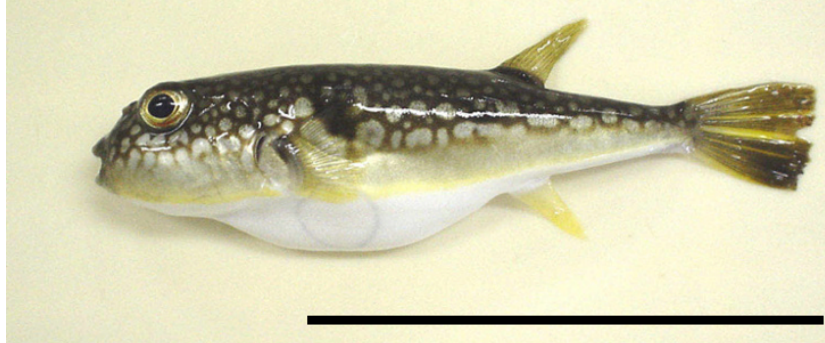

B Takifugu rubripes



D Takifugu pardalis

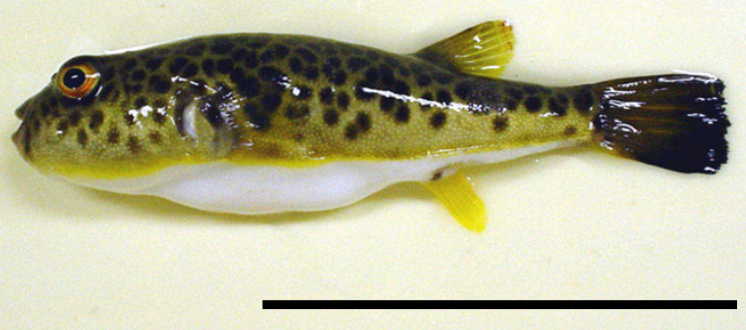

F Takifugu porphyreus



Figure I

Six Takifugu species used in this study. A. T. obscurus. B. T. rubripes. C. T. niphobles. D. T. pardalis. E. T. poecilonotus. F. T. porphyreus. Scale bars represent $50 \mathrm{~mm}$.

are different depending on animals and their habitats. Freshwater (FW) teleosts (modern bony fish) maintain the osmolarity of extracellular fluid around $300 \mathrm{mOsM}$, while the osmolarity of the environmental freshwater is generally less than $10 \mathrm{mOsM}$. In order to balance passive loss of salts and gain of water, they take up salts from FW through the gills and excrete a lot of dilute urine from which most of the salts have been reabsorbed by the kidney [1]. Marine teleosts also maintain the osmolarity of extracellular fluid to a level similar to that of freshwater fish, despite that the osmolarity of seawater (SW) is approx. 1000 mOsM. In order to balance passive loss of water and gain of salts, they drink seawater, absorb salts and water both in the intestine, and excrete salts through the gills [1]. The systems used by teleosts to adapt to FW and SW differ not only in the direction of ion and water movements but also in their molecular components. Euryhaline fish adapts to both FW and SW by switching these systems.

To identify the molecular components involved in body fluid homeostasis, the change of expression of each gene during adaptation of euryhaline fishes to different salinities is a potential useful marker since the genes involved are expected to be drastically up- or down-regulated during the adaptation. In fact, several genes have been identified by this strategy using euryhaline fishes such as tilapia [2], salmon [3-5], killifish [6], and eel [7-10]. However, this systematic approach is very laborious because genome sequences are not available for the euryhaline fishes that are currently being used for molecular physiological studies. 
Table I: List of Takifugu species used in this study.

\begin{tabular}{|c|c|c|c|c|c|}
\hline Adaptability & Species (Common name) & Environment (Total length) & Spawning & Region & Ref. \\
\hline $\begin{array}{l}\text { Seawater fish, Anadromous } \\
\text { freshwater fish }\end{array}$ & $\begin{array}{l}\text { Takifugu obscurus (Obscure puffer, } \\
\text { Mefugu) }\end{array}$ & $\begin{array}{l}\text { Sea River } \\
20-40 \mathrm{~cm}\end{array}$ & River & East Asia & {$[12,15-17,46]$} \\
\hline $\begin{array}{l}\text { Seawater fish, Peripheral } \\
\text { freshwater fish }\end{array}$ & $\begin{array}{l}\text { Takifugu niphobles (Grass puffer, } \\
\text { Kusafugu) }\end{array}$ & $\begin{array}{l}\text { Seacoast, River mouth* } \\
15 \mathrm{~cm}\end{array}$ & Sea & East Asia & {$[12,15,47]$} \\
\hline \multirow[t]{4}{*}{ Seawater fish } & $\begin{array}{l}\text { Takifugu pardalis (Panther puffer, } \\
\text { Higanfugu) }\end{array}$ & $\begin{array}{l}\text { Sea, River mouth** } \\
20-38 \mathrm{~cm}\end{array}$ & Sea & East Asia & {$[12,22]$} \\
\hline & $\begin{array}{l}\text { Takifugu poecilonotus (Fine- } \\
\text { patterned puffer, Komonfugu) }\end{array}$ & $\begin{array}{l}\text { Sea, River mouth }{ }^{* * *} \\
20 \mathrm{~cm}\end{array}$ & Sea & East Asia & {$[12,15]$} \\
\hline & $\begin{array}{l}\text { Takifugu rubripes (Ocellate puffer, } \\
\text { Tiger puffer, Torafugu) }\end{array}$ & $\begin{array}{l}\text { Sea, River mouth*** } \\
35-80 \mathrm{~cm}\end{array}$ & Sea & East Asia & {$[12,15,22]$} \\
\hline & $\begin{array}{l}\text { Takifugu porphyreus (Genuin } \\
\text { puffer, Purple puffer, Mafugu) }\end{array}$ & $\begin{array}{l}\text { Sea } \\
20-50 \mathrm{~cm}\end{array}$ & Sea & East Asia & {$[12,22]$} \\
\hline
\end{tabular}

* Adult fish are often seen in BW river mouths and sometimes seen in FW rivers.

** Adult fish are sometimes seen in BW river mouths [48].

**** Fingerlings are often seen in brackish river mouths [22].

Takifugu is a genus of puffer fish and belongs to the family Tetradontidae of teleost fish. It consists of approx. 20 species living in the Northwest Pacific Ocean around China, Korea, and Japan $[11,12]$. Takifugu species are famous for their puffing behavior, powerful toxins in the internal organs, and edible muscle. Two species are farmed on a commercial scale: $T$. rubripes is farmed in Japan and $T$. obscurus, in Korea and China. The Takifugu species have an advantage as animal model, in that they have a short genome ( $400 \mathrm{Mb})$ compared to those of other vertebrates including Homo sapiens (human, $3000 \mathrm{Mb}$ ), Mus musculus (mouse, $3000 \mathrm{Mb}$ ), Gallus gallus (chicken, 1200 $\mathrm{Mb}$ ), Xenopus laevis (African clawed frog, $3100 \mathrm{Mb}$ ), Danio rerio (zebrafish, $1700 \mathrm{Mb}$ ), and Oryzias latipes (medaka, $1100 \mathrm{Mb}$ ) [13]. In 2002, the genome project of T. rubripes was completed and the sequence information is now available for free on the websites [14].

Within the genus Takifugu, two species are known to be anadromous, namely, T. obscurus [15-19] and T. ocellatus [16]. T. obscurus (Figure 1, Table 1) is found in the East China Sea, the South China Sea, and inland waters in China and the Korean Peninsula. It lives in the bottom layer of inshore and inland waters, and grows $20-40 \mathrm{~cm}$ in length. Most of the growth takes place in the sea but they spawn in brackish and fresh water. During the spawning season, which is from late spring to early summer, the sexually mature fish run into river estuaries and spawn in inland waters including rivers, lakes, and ponds. The fingerlings grow in the inland water and either return to the sea the next spring or they there for a few months before returning to the sea. In the sea they grow to sexually mature fish over several years, and then return to the inland water again to spawn. T. ocellatus is also found in an area similar to that of T. obscurus. T. ocellatus is a small species and grows to around $15 \mathrm{~cm}$ in length. The life cycle of T. ocellatus has not been well described but is expected to be similar to that of T. obscurus.

In this study, we focus on the suitability of T. obscurus as a novel animal model for studying the molecular mechanism of body fluid homeostasis. First we compared the adaptability of T. obscurus to FW with those of other Takifugu species, and showed that only T. obscurus is fully adaptable to both SW and FW. Next we demonstrated that changes in blood $\mathrm{Na}^{+}$concentration of $T$. obscurus during FW adaptation are kept within the physiological range while those of $T$. niphobles decline beyond the range. Finally we isolated and sequenced $16 \mathrm{~S}$ ribosomal genes from six Takifugu species including T. obscurus, $T$. niphobles, and T. rubripes, and demonstrated that those sequences are 99\% identical within the genus Takifugu. With the euryhalinity and applicability of the currently available fugu genome sequence, we conclude that $T$. obscurus is a useful animal model for studying the mechanism of osmoregulation.

\section{Results}

\section{Survival of Takifugu species in FW}

A summary on six Takifugu species used in this study is shown in Figure 1 and Table 1. The survival rate of each species after transfering from SW to FW is shown in Figure $2 \mathrm{~A}$. The results show the mean values of several experiments. The mean survival in FW was: $1.2 \pm 0.2$ days, $3.6 \pm$ 0.2 days, $5.5 \pm 0.4$ days, $7.0 \pm 0.3,7.5 \pm 0.8$ days, and more than 10 days for $T$. porphyreus, T. poecilonotus, T. rubripes, $T$. niphobles, T. pardalis, and T. obscurus, respectively. In a separate experiment, we confirmed that $T$. obscurus could survive for at least 3 weeks in FW without any apparent difficulties (data not shown). These data suggest that only T. obscurus is fully adaptable to both FW and SW among the six Takifugu species tested. Of the five species that 
(A) FW

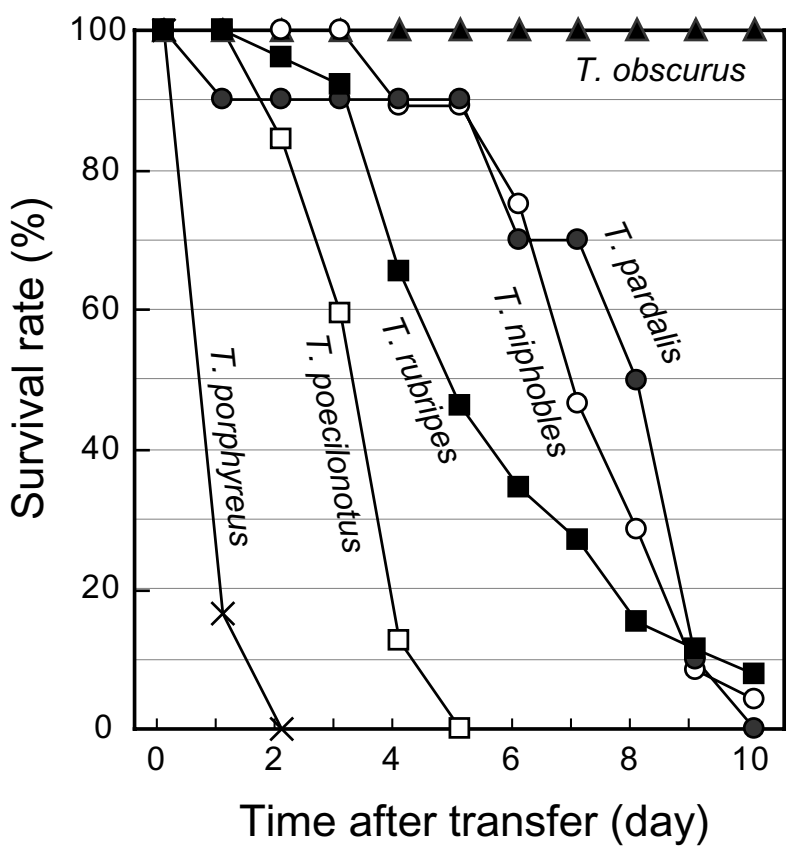

(B) $\mathrm{BW}(14 \% \mathrm{SW})$



Figure 2

Survival rates of the Takifugu species after a direct transfer from seawater (SW) to freshwater (FW) or brackish water (BW). Fourteen-percent SW was used as BW. Numbers of fishes used for the analyses were: T. obscurus, $\mathrm{n}=18$ for FW; T. niphobles, $\mathrm{n}=35$ for FW and $\mathrm{n}=36$ for BW; $T$. pardalis, $\mathrm{n}=10$ for FW and $\mathrm{n}=6$ for BW; T. poecilonotus, $\mathrm{n}=32$ for FW and $\mathrm{n}=10$ for BW; T. rubripes, $\mathrm{n}=26$ for FW and $\mathrm{n}=1 \mathrm{I}$ for BW; and $T$. porphyreus, $\mathrm{n}=6$ for FW.

could not survive in FW, four (T. niphobles, T. rubripes, $T$. pardalis and $T$. poecilonotus) were able to adapt to $\mathrm{BW}$ (14\% SW) (Figure 2B).

The fishes that survived for 10 days in BW were transferred to FW and survival was monitored (time course data not shown). Mean survival in FW were: $3.1 \pm 0.6$ days, $4.6 \pm$ 0.6 days, and $5.5 \pm 0.7$ days for $T$. niphobles $(\mathrm{n}=7), T$. poecilonotus $(\mathrm{n}=8)$, and $T$. pardalis $(\mathrm{n}=6)$, respectively. Mean survival in FW following the transfer from BW did not differ significantly between T. poecilonotus and T. pardalis, and was short for T. niphobles $(\mathrm{P}<0.001)$ when compared to the survival of those that were transferred from SW to FW. These results indicate that 10 days' adaptation to BW does not improve the adaptability of T. poecilonotus, T. pardalis, and T. niphobles to FW.

\section{Changes in serum osmolarity and concentrations of ions and urea during adaptation}

To gain insights into the way that the Takifugu species adapt to different salinities, we sampled the blood from two species, $T$. obscurus and T. niphobles, and determined serum osmolarity and concentrations of ions and urea (Table 2). In SW, serum osmolarity and ion concentration of $T$. obscurus and T. niphobles were similar to those reported for other teleost fish [1]. When transferred to FW, however, significant changes were observed in serum osmolarity and concentrations of $\mathrm{Na}^{+}$and $\mathrm{Cl}^{-}$for $T$.

Table 2: Serum osmolarity ( $\mathrm{mOsM}$ ) and concentration $(\mathrm{mM})$ of ions and urea

\begin{tabular}{|c|c|c|c|c|c|c|c|c|}
\hline Species & Condition & $\mathrm{mOsM}$ & $\mathrm{Na}^{+}$ & $\mathrm{K}^{+}$ & $\mathrm{Ca}^{2+}$ & $\mathrm{Mg}^{2+}$ & $\mathrm{Cl}^{-}$ & Urea \\
\hline \multirow[t]{2}{*}{ T. obscurus } & SW & $363 \pm 9.4$ & $179 \pm 3.9$ & $2.8 \pm 0.4$ & $3.1 \pm 0.2$ & $1.8 \pm 0.1$ & $144 \pm 3.3$ & $2.6 \pm 0.4$ \\
\hline & FW & $346 \pm 5.7$ & $166 \pm 1.2$ & $3.0 \pm 0.7$ & $3.5 \pm 0.3$ & $1.3 \pm 0.1$ & $128 \pm 2.1^{*}$ & $3.7 \pm 0.4$ \\
\hline \multirow[t]{3}{*}{ T. niphobles } & SW & $392 \pm 5.6$ & $197 \pm 3.8$ & N.D. & $2.8 \pm 0.1$ & $1.6 \pm 0.1$ & $126 \pm 3.6$ & $1.0 \pm 0.4$ \\
\hline & FW & $244 \pm 9.5^{* *}$ & $128 \pm 5.7^{* *}$ & N.D. & $2.2 \pm 0.2$ & $0.9 \pm 0.2$ & $74 \pm 2^{* *}$ & $0.4 \pm 0.1$ \\
\hline & BW & $355 \pm 33$ & $181 \pm 15$ & N.D. & $3.0 \pm 0.3$ & $2.0 \pm 0.2$ & $104 \pm 12$ & $0.6 \pm 0.1$ \\
\hline
\end{tabular}

Values are means $\pm \mathrm{SE} ; \mathrm{n}=4 .{ }^{*} p<0.01,{ }^{*} * p<0.001$ 


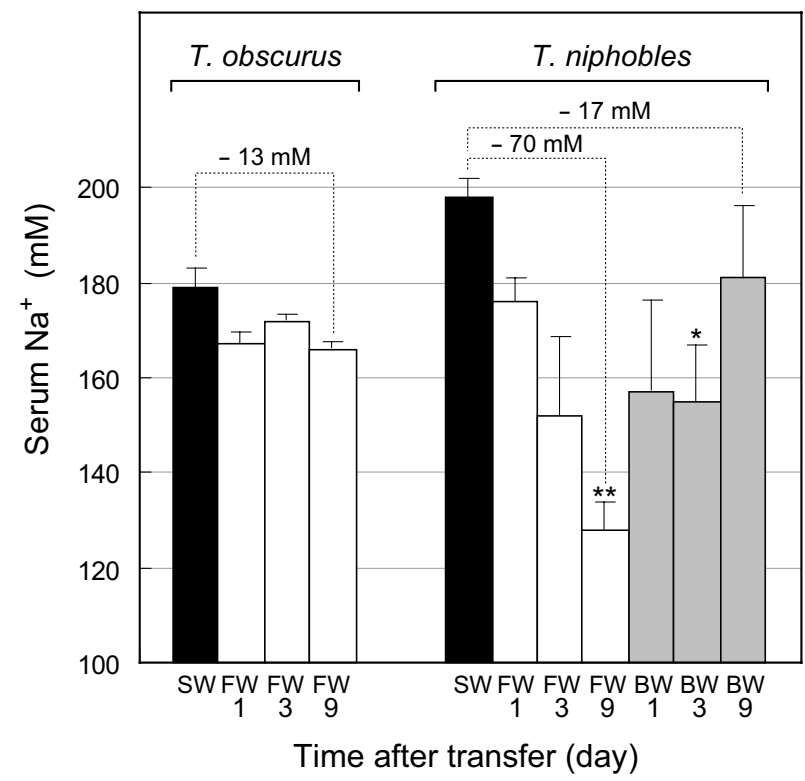

Figure 3

Changes in serum $\mathrm{Na}^{+}$concentration during transfer from seawater (SW) to freshwater (FW) or to brackish water (BW). Results of $T$. obscurus and $T$. niphobles are shown on the left and right, respectively. Serum $\mathrm{Na}^{+}$concentrations of the fish that adapted to SW, FW, and BW are shown as the black, white, and gray bars, respectively $(n=3-$ 4). I4\% SW was used as BW. $* P<0.01$, **P $<0.00$ I.

niphobles, whereas the changes were small for T. obscurus. The reductions in osmolarity during FW adaptation of $T$. obscurus and T. niphobles were -17 and -148 mOsM, respectively. The decrements of serum concentrations of $\mathrm{Na}^{+}$and $\mathrm{Cl}^{-}$during FW adaptation were -13 and $-16 \mathrm{mM}$ in $T$. obscurus, and -69 and $-52 \mathrm{mM}$ in $T$. niphobles, respectively. These results suggest that $T$. obscurus has a much stronger ability to maintain body fluid homeostasis against salinity fluctuations and can survive in FW.

Figure 3 shows the time course of changes in serum $\mathrm{Na}^{+}$ concentration following exposure of T. obscurus and $T$. niphobles to low salinities. In the case of T. obscurus, a slightly decreased level that was observed on day 1 , remained throughout the course, but in the case of $T$. niphobles, a relatively large decrease occurred continuously until death. In BW where T. niphobles exhibited 64\% survival rate (Figure 2), a significant recovery of the decreased serum $\mathrm{Na}^{+}$levels was observed on day 9 (Figure 3 ). The standard errors of serum $\mathrm{Na}^{+}$concentration of $T$. niphobles (7.6-32 $\mathrm{mM}$ ) were much larger than those of T. obscurus (2.3-7.9 $\mathrm{mM})$, suggesting that the individual differences of adaptability to FW and BW are large in T. niphobles. In $T$. niphobles the decrease in serum $\mathrm{Cl}^{-}$was more extensive than that in serum $\mathrm{Na}^{+}$. In T. obscurus serum $\mathrm{Cl}^{-}$decreased while $\mathrm{Na}^{+}$and osmolarity remained unchanged.

\section{Comparison of nephron structure of Takifugu species}

Kidney sections of the six Takifugu species were analyzed to compare their nephron structures. Under light microscope, a number of glomeruli were observed within all sections stained with hematoxylin-eosin, demonstrating that all six Takifugu species have glomerular nephrons (Figure 4A-C). The glomeruli of FW-acclimated T. obscurus appeared to be loose compared to those of the SWacclimated fish (Figure 4D-E). There was no clear difference between those species rich in glomeruli at the histological level.

To characterize the segments of the renal tubules, kidney sections of T. obscurus, T. rubripes, T. niphobles, T. pardalis, and $T$. poecilonotus were stained with anti- $\mathrm{Na}^{+}-\mathrm{K}^{+}$-ATPase (NKA) antibody, and observed under a fluorescence microscope. NKA is the most important molecule that provides a driving force for many transporting systems in the renal tubules, and the patterns of NKA localization are different among the segments of renal tubule (Figure 4IJ) [20]. In both FW- and SW-acclimated T. obscurus, proximal and distal segments were clearly observed (Figure $4 \mathrm{~F}-\mathrm{G}$ ). In contrast, the distal segment is not found in $T$. rubripes, T. niphobles, T. pardalis, and T. poecilonotus (Figure $4 \mathrm{H})$.

\section{Phylogeny of Takifugu species}

To know the phylogenetic relationship of the Takifugu species, we isolated the mitochondrial 16S rRNA gene from each species and determined the sequence. Resulting data were compared with the sequences of the 16S rRNA genes of other species in databases, and a phylogenetic tree was constructed (Figure 5). Surprisingly, the Takifugu species were very closely related each other. The identities of $16 \mathrm{~S}$ rRNA within the Takifugu species are 99\% whereas those between Takifugu and Tetraodon nigroviridi, Oryzias latipes, or Homo sapiens were $86 \%, 77 \%$, and 63\%, respectively. Our preliminary results of the nucleotide sequences of several cDNA clones for ion transporters $\left(\mathrm{Na}^{+} / \mathrm{H}^{+}\right.$ exchangers; accession numbers AB200326-AB200333) and hormone receptors (members of the adrenomedullin receptor family: accession numbers AB219765AB219771, AB219835-AB219840) [21] of T. obscurus were $99 \%$ identical to those of $T$. rubripes including the non-coding sequences (data not shown). These results suggest that the Takifugu species diversified very recently and the genome resources of $T$. rubripes can be used for studying the T. obscurus genes and their products.

\section{Discussion}

Through analyses of the ability of the Takifugu species to adapt to FW, we have demonstrated that only T. obscurus 




\section{Figure 4}

Renal structure of Takfiugu kidneys. A-E. Paraffin-embedded sections of the kidneys of indicated Takifugu species were stained with hematoxylin and eosin and examined for abundance of glomeruli. All the other species, T. niphobles, T. pardalis, T. poecilonotus, and T. porphyreus, also have glomerulous nephron (data not shown). D. Higher magnification view of the glomeruli of FW-acclimated T. obscurus indicated by a box in A. E. Higher magnification views of the glomeruli of SW-acclimated T. obscurus indicated by boxes in B. F-H. Paraffin-embedded sections of the kidneys of indicated Takifugu species were stained with anti-Na $\mathrm{N}^{+} \mathrm{K}^{+}$-ATPase (NKA) antibody (green) and Hoechst 33342 (red). NKA antibody strongly stained basolateral surface of proximal segment $(\mathrm{P})$ and entire cell of distal segment (d). T. niphobles, T. pardalis, and T. poecilonotus showed similar result to T. rubripes (data not shown). I-J. Frozen sections of the kidneys of T. obscurus were stained with anti-NKA antibody (red) and Alaxa Fluor 488-labeled phalloidin (green). Phalloidin binds to actin filaments, and strongly stains a well-developed apical brush border of proximal segments. I. Proximal segment of the nephron of T. obscurus. J. Distal segment of the nephron of $T$. obscurus. All scale bars represent $50 \mu \mathrm{m}$. 


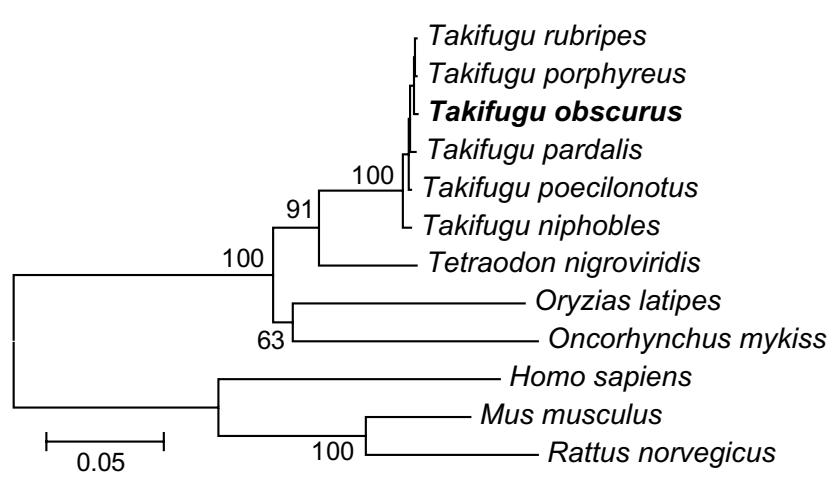

Figure 5

Phylogenetic relationship between Takifugu and other species. I.I-kb nucleotide sequences of the mitochondrial I6S ribosomal RNA gene of each species were used for the analyses. Bootstrap values from 2,000 times replications are indicated at major nodes. Bars indicate $5 \%$ replacement of a nucleotide per site. Accession numbers were as follows: $T$. niphobles, $\mathrm{AB} 1993$ 18; T. poecilonotus, ABI99319; T. pardalis, AB 199320; T. rubripes, ABI9932I; $T$. obscurus, $\mathrm{AB}$ I 99322; T. porphyreus, $\mathrm{AB}$ I 99323; T. nigroviridis, CR688806; O. latipes, NC_004387; O. mykiss, NC_00 I 7I 7; $H$. sapiens, J0I4I5; M. musculus, J0I420; and R. norvegicus, XI4848.

exhibits a high adaptability to both FW and SW. This observation is consistent with their natural anadromous habitats (Table 1). In our analyses, we used sexually immature fish ( 10 g) and large fish ( 350 g) with well developed testis or ovary. All the T. obscurus survived in both FW and SW for more than 10 days and they looked healthy, suggesting that size and sexual maturation do not affect their adaptability. Recently, Yan et al. reported the effect of salinity on food intake, growth, and survival of $T$. obscurus ( 45 g) [19]. They cultured T. obscurus in FW, BW, and SW for 54 days and compare their level of food-intake and growth rates. The fish survived and grew under all conditions tested, and the growth rates in low-salinity BW (23\% SW) were better than those in FW, SW and highsalinity BW (51\% SW). Their observation demonstrated that $T$. obscurus grows under a wide range of salinities and low-salinity BW is the best condition for young T. obscurus to grow.

Our analyses also demonstrated that many other Takifugu species exhibit a relatively high ability to cope with salinity changes. T. niphobles, T. rubripes, T. pardalis, and T. poecilonotus can survive in FW for several days and in BW for more than 10 days, suggesting that the Takifugu species are potentially euryhaline. These results are consistent with their natural brackish/marine habitats; they are sometimes found in brackish river mouths (Table 1). It is known that $T$. rubripes spawn in the entrance of bays. The fingerlings grow in shallow and river mouths of bays for one year, and then go to the broad ocean [22]. Han et al. demonstrated that the best growing salinity of $T$. rubripes weighting 0.02, 1.2 and 25 g were 73-91\%, 29\%, and $43 \%$ SW, respectively [23]. Thus change of the environmental salinity is important for the growth of the fingerlings of T. rubripes.

During the acclimation to FW, serum $\mathrm{Cl}^{-}$of $T$. obscurus decreased although $\mathrm{Na}^{+}$and osmolarity remained unchanged. In T. niphobles the decrease in serum $\mathrm{Cl}^{-}$was more extensive than that in serum $\mathrm{Na}^{+}$. These results suggest that the mechanisms whereby $\mathrm{Cl}^{-}$and $\mathrm{Na}^{+}$are regulated differ. The decrease in serum $\mathrm{Cl}^{-}$during FW acclimation has also been observed in Japanese eel (Anguilla japonica) [24] and spotted green pufferfish (Tetraodon nigroviridis) [20]. In Tetraodon and Takifugu species, the other electrolytes that compensate for $\mathrm{Cl}^{-}$were not determined. In the case of Japanese eel, serum $\mathrm{SO}_{4}{ }^{2-}$ concentration increases from $\sim 1$ to $\sim 19 \mathrm{mM}$ during acclimation from SW to FW [24]. The expressions of kidney sulfate transporters are drastically induced during FW acclimation, suggesting that the serum $\mathrm{SO}_{4}{ }^{2-}$ reabsorbed by the kidney compensates for $\mathrm{Cl}^{-}$and helps improve the survival of eel in FW [24].

Some reports have categorized pufferfish as aglomerular $[25,26]$. However, glomerular nephrons was observed in the species of from four genuses of the Tetraodontidae family, namely, Canthigaster rivulatus [27], Tetraodon nigroviridis [20], Sphoeroides testudineus [28], two Takifugu species reported by Ogawa [27], and six Takifugu species in this study (Figure 4). We think that many of the Tetraodontidae species are glomerular. The increase in size of the glomerulus after transferring to FW (Figure 4D-E) was also found in the threespine stickleback (Gasterosteus aculeatus L.) [29]. In general, the largest difference between FW fish and glomerular SW fish regarding structure of the renal tubules is the presence or absence of a distal segment, which acts as a urine-diluting segment in FW fish [30]. Most of the euryhaline fish have a FW-fish type of nephron such as the European eel (Anguilla vulgaris), Pacific pink salmon (Oncorhynchus gorbuscha), rainbow trout (Oncorhynchus mykiss), southern flounder (Paralichthys lethostigma), armored sculpin (Leptocottus armatus), medaka (Oryzias latipes), and spotted green pufferfish $[20,30]$. In the Takifugu species, we demonstrated that only mefugu (T. obscurus) has the FW-fish type of nephron with a distal segment, and the other species have a SW-fish type of nephron lacking a distal segment (Figure 4F-J). These results are completely consistent with the ability of those species to adapt to FW, thus the presence of a distal segment is one of the most important factors that allow $T$. obscurus to be highly adaptalbe to a wide range of salinities. 
Tetraodon nigroviridis (spotted green pufferfish) is a small pufferfish less than $10 \mathrm{~cm}$ in length that lives in brackish river and estuaries of Southeast Asia. T. nigroviridis also has a compact genome like the Takifugu species, and the whole genome was sequenced in 2004 [31]. Recently, Lin et al. have demonstrated the strong adaptability of $T$. nigroviridis to $\mathrm{FW}, \mathrm{BW}$, and $\mathrm{SW}$ and its use in studies on osmoregulation [20]. We think that both T. nigroviridis and T. obscurus are good models for studying osmoregulation. The advantage with $T$. nigroviridis is that it is readily available. The advantage with $T$. obscurus is that it can be used in a wide range of size $(2-20 \mathrm{~cm})$ and compare the functions of the gill and kidney with those of other Takifugu species that can not adapt to FW.

Many molecules have been identified as components of the chloride cells (or mitochondria-rich cells), the major site of ion regulation in the gill: transporters, channels, and pumps for $\mathrm{Na}^{+}, \mathrm{K}^{+}, \mathrm{Cl}^{-}, \mathrm{HCO}_{3}{ }^{-}, \mathrm{H}^{+}, \mathrm{Ca}^{2+}$, water, and urea; carbonic anhydrase; and hormone receptors [32]. However, the complete physiological function of the chloride cells cannot be explaned by those components alone, and identification of further players is necessary. Furthermore, little is known of the molecular biology of osmoregulation by the kidney and intestine of teleost fish: NKA [20], sulphate transporters [24], urea transporter [33], chloride channel [34], $\mathrm{Ca}^{2+}$-sensing receptor [35], Vtype $\mathrm{H}^{+}$-ATPases [36] in the kidney; Na-Pi cotransporter [37] and aquaporin water channels in both the kidney and intestine [38-40]; and $\mathrm{Na}^{+} / \mathrm{K}^{+} / 2 \mathrm{Cl}^{-}$cotransporter in the stomach and intestine [41]. By determining the differences in gene expression patterns in the gill, intestine, and kidney of FW- and SW-acclimated mefugu (T. obscurus), we would be able to identify the genes that are important for osmoregulatory adaptation.

\section{Conclusion}

- Mefugu (T. obscurus) is an anadromous fish of the genus Takifugu that has a strong ability to maintain body fluid homeostasis during adaptation to low and high environmental salinities and is fully adaptable to both FW and SW.

- Members of the genus Takifugu are very closely related and share $~ 99 \%$ sequence identities in their genomes as shown by a phylogenetic analysis using the mitochondrial DNA sequence for the 16S ribosomal RNA gene.

- The nephrons of FW- or SW-acclimated T. obscurus exhibit a structure that is typical of FW fish. On the other hand, T. rubripes, T. niphobles, T. pardalis, T. poecilonotus, and $T$. porphyreus have nephrons of that are typical of SW glomerular fish.
- T. obscurus can be used as an animal model for studying the molecular mechanism of osmoregulation by exploiting the Takifugu genome resources.

\section{Methods}

\section{Animals and transfer experiment}

The animal protocols and procedures were approved by the Institutional Animal Care and Use Committee of Tokyo Institute of Technology and conformed to the American Physiological Society's Guiding Principles in the Care and Use of Laboratory Animals. T. obscurus (10-350 g) were cultured in a brackish river in Korea and China. The fish cultured in BW (14\% SW) were transported to The Shimonoseki Marine Science Museum in Japan and kept in 150-2000-l tanks containing BW. The fish were then acclimated to SW for 7-14 days. None of the fish died during the acclimation to SW. To determe FW adaptability, the SW in the tank was gradually replaced with FW by pouring FW at a speed that allowed a complete replacement after 1-2 h. Some fish were transferred to FW directly. Survival was then monitored every $12 \mathrm{~h}$ for 10 days.

Other species were caught or cultured in seawater. $T$. rubripes (30-4200 g) were cultured and sampled at the Japan Sea. T. niphobles (18-128 g), T. pardalis (29-175 g), T. poecilonotus (18-43 g), and T. porphyreus (521-1000 g) were sampled at the Japan Sea. They were transported to the Aquarium and kept in 200-5700-l tanks containing SW. Their adaptability to FW and BW were determined as described above.

All fish used in the analyses were adult fish. The normal size of each species is shown in Table I. Most of the T. niphobles, T. pardalis, T. poecilonotus, and T. porphyreus were sexually mature adult fish. T. obscurus and T. rubripes were mixtures of mature and immature fish. The distinction between the species was performed according to Nakabo [11].

\section{Blood analyses}

T. obscurus and T. niphobles were maintained in SW and transferred to FW or BW (14\% SW). Bloods were collected from the fish in SW and those in FW or BW after 1, 3, and 9 days of the transfer. Healthy fish that had adapted to in various conditions were anaesthetized by immersion in $0.1 \%$ ethyl $m$-aminobenzoate methanesulfonate, and blood was collected from the hepatic vein or heart. Serum from $T$. obscurus and T. niphobles were diluted in water at the ratio of $1: 2$ and 1:8, respectively, and used for the analyses. Serum osmolarity was measured by a cryoscopic method. Concentrations of $\mathrm{Na}^{+}, \mathrm{K}^{+}$, and $\mathrm{Cl}^{-}$were measured by the established electrode methods. $\mathrm{Ca}^{2+}$ and $\mathrm{Mg}^{2+}$ concentrations were determined by the $o$-cresolphthalein complexone method and xylysine blue method, respec- 
tively. Urea nitrogen concentration in the serum was measured by standard urease assay. The dilution of serum in water did not affect the results (data not shown). These measurements were conducted by SRL Laboratories (Tokyo, Japan).

\section{Histochemistry}

Kidneys of pufferfish were fixed in $4 \%$ paraformaldehyde in $0.1 \mathrm{M}$ phosphate buffer, $\mathrm{pH} 7.4$, embedded in paraffin, sectioned, and stained with hematoxylin and eosin according to standard procedures.

For the immunohisotchemical analyses, the kidneys were fixed in $4 \%$ paraformaldehyde in $0.1 \mathrm{M}$ phosphate buffer, $\mathrm{pH} 7.4$, at $4^{\circ} \mathrm{C}$ for $2 \mathrm{~h}$, and rinsed in phosphate-buffered saline (PBS: $137 \mathrm{mM} \mathrm{NaCl}, 2.7 \mathrm{mM} \mathrm{KCl}, 6.5 \mathrm{mM}$ $\mathrm{Na}_{2} \mathrm{HPO}_{4}, 1.5 \mathrm{mM} \mathrm{KH}_{2} \mathrm{PO}_{4}, \mathrm{pH} 7.4$ ) containing $10 \%(\mathrm{w} /$ v) sucrose. The fixed tissues were cryoprotected through a range of increasing sucrose concentrations up to $20 \%$, quick frozen in an optimum cutting temperature compound (Tissue Tek).

The frozen sections $(6 \mu \mathrm{m})$ and paraffin-embedded sections $(6 \mu \mathrm{m})$ were prepared, permeabilized with $0.1 \%$ Triton $\mathrm{X}-100$ in PBS at $20^{\circ} \mathrm{C}$ for $10 \mathrm{~min}$, incubated with $5 \%$ fetal bovine serum (FBS) in PBS at $20^{\circ} \mathrm{C}$ for $1 \mathrm{~h}$, and incubated with anti-Na+- $\mathrm{K}^{+}$-ATPase rabbit antiserum [8] $(1: 1,000)$ in PBS containing $5 \%$ FBS at $20^{\circ} \mathrm{C}$ for $8 \mathrm{~h}$. After washing with PBS, the sections were incubated with a mixture of Alexa Fluor-488- or Alexa Fluor-546-labeled secondary antibody (Molecular Probes; 1:2,000 dilution), Alexa Fluor-488-labeled phalloidin (Molecular Probes; $0.15 \mu \mathrm{M}$ ), and Hoechst 33342 (Molecular Probes; $100 \mathrm{ng}$ / $\mathrm{ml}$ ) in PBS containing 5\% FBS at $20^{\circ} \mathrm{C}$ for $1 \mathrm{~h}$. The sections were mounted on antifade glycerol $(90 \%$ glycerol, $10 \% 10 \times$ PBS, and $0.1 \%$ 1,4-phenylenediamine, $\mathrm{pH} 7.4$ ). Fluorescence was detected using a fluorescence microscope (Carl Zeiss). The images were obtained with a highresolution digital charge-coupled device (CCD) camera (AxioCam HRm, Carl Zeiss) and processed with an AxioVision 4.1 software (Carl Zeiss).

The following pufferfish were used for the analyses: $T$. obscurus acclimated to FW for 9 days; T. obscurus acclimated to SW for 9 days; T. rubripes, T. niphobles, T. pardalis, T. poecilonotus, and T. porphyreus maintained in SW.

\section{Phylogenetic analyses}

Mitochondrial DNA from T. obscurus, T. rubripes, $T$. niphobles, T. pardalis, T. poecilonotus, and T. porphyreus was extracted from the fin, and used for isolation of genes for 16S rRNA by PCR as described elsewhere [42]. Two sets of primers were used: L1854 (5'-AAACCTCGTACCTTTTGCAT-3') and H2582 (5'-ATTGCGCTACCTTTGCACGGT3') for amplification of the anterior half of the 16S rRNA genes, and L2503 (5'-CACAAGCCTCGCCTGTTTACCA$\left.3^{\prime}\right)$ and H3058 (5'-TCCGGTCTGAACTCAGATCACGTA$\left.3^{\prime}\right)$ for the amplification of the posterior half. Products of PCR were purified and directly sequenced by the dideoxy chain termination method with an automated DNA sequencer (Model 310; Applied Biosystems, Foster City, $\mathrm{CA}$ ). The GenBank accession number for the sequence of each gene is as follows: $T$. niphobles, AB199318; $T$. poecilonotus, AB199319; T. pardalis, AB199320; T. rubripes, AB199321; T. obscurus, AB199322; and T. porphyreus, AB199323.

For the evolutionary analyses, the nucleotide sequences were aligned using Clustal W software [43], and then a phylogenetic tree was constructed by the neighbor-joining method [44] using MEGA software [45] based on JukesCantor evolutionary distances [44]. Statistical analysis was performed by bootstrap methods [44].

\section{List of abbreviations}

SW - seawater, FW - freshwater, BW - brackish water

\section{Authors' contributions}

$\mathrm{AK}$ and SH planned of and designed the study, and wrote the manuscript. HD planned the sections of the study, and performed the operations relating to the supply, transfer, and maintenance of the fish. HD and AK performed the salinity transfer analyses. HS cloned and sequenced genes for 16S rRNA, and collected information on ecobiology of the Takifugu species. AK performed blood assays and construction of the phylogenetic tree. TN performed the histochemical analyses. All authors read and approved the final manuscript.

\section{Acknowledgements}

We thank Toshiaki Ishibashi, Kenji Mizushima, and Masashi Wada for their assistance with use of the facilities in the aquarium, Tomo Akita, Kumi Kimura, and Rieko Akashi for maintaining the fish, Koji Ishigaki for transferring the $T$. obscurus from South Korea, Chunshen Li and Osame Tabeta for translating reference for 17 in Chinese language, Yukihiro Kurita for the discussion, and Setsuko Sato for the secretarial assistance. This work was supported by Grants-in-Aid for Scientific Research (14104002, 16710145) from the Ministry of Education, Culture, Sport, Science and Technology of Japan (MEXT) and the 2 Ist Century COE Program of MEXT.

\section{References}

I. Karnaky KJ: Osmotic and ionic regulation. In The Physiology of Fishes Edited by: Evans DH. Boca Raton (Florida): CRC Press; 1998:157-176.

2. Fiol DF, Kultz D: Rapid hyperosmotic coinduction of two tilapia (Oreochromis mossambicus) transcription factors in gill cells. Proc Natl Acad Sci U S A 2005, 102:927-932.

3. Pan F, Zarate J, Bradley TM: A homolog of the E3 ubiquitin ligase $\mathbf{R b x I}$ is induced during hyperosmotic stress of salmon. Am J Physiol Regul Integr Comp Physiol 2002, 282:R I643-RI653.

4. Pan F, Zarate J, Choudhury A, Rupprecht R, Bradley TM: Osmotic stress of salmon stimulates upregulation of a cold inducible RNA binding protein (CIRP) similar to that of mammals and amphibians. Biochimie 2004, 86:45|-46I. 
5. Smith TR, Tremblay GC, Bradley TM: Hsp70 and a $\mathbf{5 4}$ kDa protein (Osp54) are induced in salmon (Salmo salar) in response to hyperosmotic stress. J Exp Zool 1999, 284:286-298.

6. Scott GR, Richards JG, Forbush B, Isenring P, Schulte PM: Changes in gene expression in gills of the euryhaline killifish Fundulus heteroclitus after abrupt salinity transfer. Am J Physiol Cell Physiol 2004, 287: C300-C309.

7. Mistry AC, Kato A, Tran YH, Honda S, Tsukada T, Takei Y, Hirose S: FHL5, a novel actin-binding protein, is highly expressed in eel gill pillar cells and responds to wall tension. Am J Physiol Regul Integr Comp Physiol 2004, 287:R I I4I-R I I 54.

8. Mistry AC, Honda S, Hirata T, Kato A, Hirose S: Eel urea transporter is localized to chloride cells and is salinity dependent. Am J Physiol Regul Integr Comp Physiol 200I, 28 I:R I594-R I 604.

9. Suzuki Y, Itakura M, Kashiwagi M, Nakamura N, Matsuki T, Sakuta $\mathrm{H}$, Naito N, Takano K, Fujita T, Hirose S: Identification by differential display of a hypertonicity-inducible inward rectifier potassium channel highly expressed in chloride cells. J Biol Chem 1999, 274:1।376-II382.

10. Miyamoto K, Nakamura N, Kashiwagi M, Honda S, Kato A, Hasegawa $S$, Takei $Y$, Hirose S: RING finger, B-box, and coiled-coil (RBCC) protein expression in branchial epithelial cells of Japanese eel, Anguilla japonica. Eur J Biochem 2002, 269:6152-6161.

II. Nakabo T: Fishes of Japan - with pictorial keys to the species English edition. Tokyo: Tokai University Press; 2002.

12. Masuda H, Amaoka K, Araga C, Uyeno T, Yoshino T: The Fishes of the Japanese Archipelago Tokyo: Tokai University Press; 1984.

13. Venkatesh B, Gilligan P, Brenner S: Fugu: a compact vertebrate reference genome. FEBS Lett 2000, 476:3-7.

14. Aparicio S, Chapman J, Stupka E, Putnam N, Chia JM, Dehal P, Christoffels A, Rash S, Hoon S, Smit A, Gelpke MD, Roach J, Oh T, Ho IY, Wong M, Detter C, Verhoef F, Predki P, Tay A, Lucas S, Richardson P, Smith SF, Clark MS, Edwards YJ, Doggett N, Zharkikh A, Tavtigian SV, Pruss D, Barnstead M, Evans C, Baden H, Powell J, Glusman G, Rowen L, Hood L, Tan YH, Elgar G, Hawkins T, Venkatesh B, Rokhsar $D$, Brenner $S$ : Whole-genome shotgun assembly and analysis of the genome of Fugu rubripes. Science 2002, 297: I30I-I3I0.

15. Kim IS: Freshwater Fishes Seoul: Samhwa Publishing; 1997. [Ministry of Education (Series Editor): Illustrated Encyclopedia of Fauna \& Flora of Korea, vol 37.]

16. Wu HL, Jin XB, Ni Y: Toxic and Pharmacological Fish in China Shanghai: Shanghai Scientific \& Technical Publishers; 1978.

17. Xu C: Takifugu obscurus (Abe). In The Fishes of Shanghai Area Edited by: East China Sea Fisheries Institute, Chinese Academy of Fisheries Science. Shanghai: Shanghai Scientific \& Technical Publishers; 1990:377-378.

18. Yang Z, Chen YF: Induced ovulation in obscure puffer Takifugu obscurus by injections of LHRH-a. Aquacul Int 2004, I 2:2 I5-223.

19. Yan M, Li Z, Xiong B, Zhu J: Effects of salinity on food intake, growth, and survival of pufferfish (Fugu obscurus). J Appl Ichthyol 2004, 20: I46-I49.

20. Lin $\mathrm{CH}$, Tsai RS, Lee TH: Expression and distribution of $\mathbf{N a}, \mathbf{K}$ ATPase in gill and kidney of the spotted green pufferfish, Tetraodon nigroviridis, in response to salinity challenge. Comp Biochem Physiol A Mol Integr Physiol 2004, I 38:287-295.

21. Nag K, Kato A, Nakada T, Hoshijima K, Mistry AC, Takei Y, Hirose $\mathrm{S}$ : Molecular and functional characterization of adrenomedullin receptors in pufferfish. Am J Physiol Regul Integr Comp Physiol 2006, 290:R467-R478.

22. Fujita S: Studies on life history and aquaculture of Japanese puffer fishes. Rep Nagasaki Pref Inst Fish 1962, 2: I-121.

23. Han K, Chuang H, Matsui S, Furuichi M, Kitajima C: Effect of ambient salinity on growth, survival rate, and feed efficiency in the early stage of puffer fish Takifugu rubripes. Nippon Suisan Gakkaishi 1995, 6I:21-26.

24. Nakada T, Zandi-Nejad K, Kurita Y, Kudo H, Broumand V, Kwon CY, Mercado A, Mount DB, Hirose S: Roles of Slcl3al and SIc26al sulfate transporters of eel kidney in sulfate homeostasis and osmoregulation in freshwater. Am J Physiol Regul Integr Comp Physiol 2005, 289:R575-R585.

25. Vize PD: A Homeric view of kidney evolution: A reprint of H.W. Smith's classic essay with a new introduction. Anat $\operatorname{Rec}$ A Discov Mol Cell Evol Biol 2004, 277:344-354.

26. Edwards JG: Studies on aglomerular and glomerular kidneys. Am J Anat 1928, 42:75-107.
27. Ogawa M: Comparative study on the internal structure of the teleostean kidney. Sci Rept Saitama Univ 1962, B4: 107-I29.

28. Prodocimo V, Freire CA: Glomeruli and renal tubules are restricted to the cranial kidney of the adult estuarine Sphoeroides testudineus. J Fish Biol 2003, 63: 1258-1265.

29. Ogawa M: Seasonal difference of glomerular change of marine form of the stickleback, Gasterosteus aculeatus L. after transferred into fresh water. Sci Rept Saitama Univ 1968, B5: I 17- 123.

30. Hickman CP Jr, Trump BF: The Kidney. In Fish Physiology Edited by: Hoar WS, Randall DJ. New York: Academic Press; 1969:91-239.

3I. Jaillon O, Aury JM, Brunet F, Petit JL, Stange-Thomann N, Mauceli E, Bouneau L, Fischer C, Ozouf-Costaz C, Bernot A, Nicaud S, Jaffe D, Fisher S, Lutfalla G, Dossat C, Segurens B, Dasilva C, Salanoubat M, Levy M, Boudet N, Castellano S, Anthouard V, Jubin C, Castelli V, Katinka M, Vacherie B, Biemont C, Skalli Z, Cattolico L, Poulain J, De BV, Cruaud C, Duprat S, Brottier P, Coutanceau JP, Gouzy J, Parra G, Lardier G, Chapple C, McKernan KJ, McEwan P, Bosak S, Kellis M, Volff JN, Guigo R, Zody MC, Mesirov J, Lindblad-Toh K, Birren B, Nusbaum C, Kahn D, Robinson-Rechavi M, Laudet V, Schachter V, Quetier F, Saurin W, Scarpelli C, Wincker P, Lander ES, Weissenbach J, Roest $\mathrm{CH}$ : Genome duplication in the teleost fish Tetraodon nigroviridis reveals the early vertebrate proto-karyotype. Nature 2004, 431 : $946-957$.

32. Hirose S, Kaneko T, Naito N, Takei Y: Molecular biology of major components of chloride cells. Comp Biochem Physiol B Biochem Mol Biol 2003, 136:593-620.

33. Mistry AC, Chen G, Kato A, Nag K, Sands JM, Hirose S: A novel type of urea transporter, UT-C, is highly expressed in proximal tubule of seawater eel kidney. Am J Physiol Renal Physiol 2005, 288:F455-F465.

34. Miyazaki H, Kaneko T, Uchida S, Sasaki S, Takei Y: Kidney-specific chloride channel, OmClC-K, predominantly expressed in the diluting segment of freshwater-adapted tilapia kidney. Proc Natl Acad Sci U S A 2002, 99:15782-15787.

35. Loretz CA, Pollina C, Hyodo S, Takei Y, Chang W, Shoback D: cDNA cloning and functional expression of a $\mathrm{Ca}^{2+}$-sensing receptor with truncated C-terminal tail from the Mozambique tilapia (Oreochromis mossambicus). J Biol Chem 2004, 279:53288-53297.

36. Perry SF, Furimsky M, Bayaa M, Georgalis T, Shahsavarani A, Nickerson JG, Moon TW: Integrated responses of $\mathrm{Na}^{+} / \mathrm{HCO}_{3}$ cotransporters and $\mathrm{V}$-type $\mathrm{H}^{+}$-ATPases in the fish gill and kidney during respiratory acidosis. Biochim Biophys Acta 2003, 1618:175-184.

37. Kohl B, Herter $P$, Hulseweh B, Elger M, Hentschel H, Kinne RK, Werner $\mathrm{A}: \mathrm{Na}-\mathrm{Pi}$ cotransport in flounder: same transport system in kidney and intestine. Am J Physiol 1996, 270:F937-F944.

38. Aoki M, Kaneko T, Katoh F, Hasegawa S, Tsutsui N, Aida K: Intestinal water absorption through aquaporin I expressed in the apical membrane of mucosal epithelial cells in seawateradapted Japanese eel. J Exp Biol 2003, 206:3495-3505.

39. Martinez AS, Cutler CP, Wilson GD, Phillips C, Hazon N, Cramb G: Regulation of expression of two aquaporin homologs in the intestine of the European eel: effects of seawater acclimation and cortisol treatment. Am J Physiol Regul Integr Comp Physiol 2005, 288:RI733-RI743.

40. Martinez AS, Cutler CP, Wilson GD, Phillips C, Hazon N, Cramb G: Cloning and expression of three aquaporin homologues from the European eel (Anguilla anguilla): effects of seawater acclimation and cortisol treatment on renal expression. Biol Cell 2005, 97:615-627.

4l. Cutler CP, Cramb G: Two isoforms of the $\mathrm{Na}^{+} / \mathrm{K}^{+} / 2 \mathrm{Cl}^{-}$cotransporter are expressed in the European eel (Anguilla anguilla). Biochim Biophys Acta 2002, I 566:92-103.

42. Watanabe K, Iguchi K, Hosoya K, Nishida M: Phylogenetic relationships of the Japanese minnows, Pseudorasbora (Cyprinidae), as inferred from mitochondrial I6S rRNA gene sequences. Ichthyol Res 2000, 47:43-50.

43. Thompson JD, Higgins DG, Gibson TJ: CLUSTAL W: improving the sensitivity of progressive multiple sequence alignment through sequence weighting, position-specific gap penalties and weight matrix choice. Nucleic Acids Res 1994, 22:4673-4680.

44. Nei M, Kumar S: Molecular Evolution and Phylogenetics New York: Oxford University Press Inc; 2000. 
45. Kumar S, Tamura K, Jakobsen IB, Nei M: MEGA2: molecular evolutionary genetics analysis software. Bioinformatics 200I, 17:1244-1245.

46. Abe T: Taxonomic studies on the puffers (Tetraodontidae, Teleostei) from Japan and adjacent regions - V. Synopsis of the puffers from Japan and adjacent regions. Bull Biogeogr Soc Jpn 1949:89-140.

47. Miyadi D, Kawanabe H, Mizuno N: Colored Illustrations of the Freshwater Fishes of Japan New edition. Osaka: Hoikusha Publishing; 1976.

48. Society for nature conservation research of Fukui prefecture: Animals of inland waters of Fukui prefecture Fukui: Fukui prefecture; 1998.

Publish with Bio Med Central and every scientist can read your work free of charge

"BioMed Central will be the most significant development for disseminating the results of biomedical research in our lifetime. " Sir Paul Nurse, Cancer Research UK

Your research papers will be:

- available free of charge to the entire biomedical community

- peer reviewed and published immediately upon acceptance

- cited in PubMed and archived on PubMed Central

- yours - you keep the copyright

Submit your manuscript here:

http://www.biomedcentral.com/info/publishing_adv.asp
BioMedcentral 